Review

\title{
The Three Bacterial Lines of Defense against Antimicrobial Agents
}

\author{
Gang Zhou ${ }^{1,2,3}$, Qing-Shan Shi ${ }^{1,2,3, *}$, Xiao-Mo Huang ${ }^{1,2,3}$ and Xiao-Bao Xie 1,2,3 \\ 1 Guangdong Institute of Microbiology, Guangzhou 510070, Guangdong, China; \\ E-Mails: zgbees@gdim.cn (G.Z.); xmhuang@gdim.cn (X.-M.H.); xiaobaoxie@126.com (X.-B.X.) \\ 2 State Key Laboratory of Applied Microbiology Southern China, Guangzhou 510070, \\ Guangdong, China \\ 3 Guangdong Provincial Key Laboratory of Microbial Culture Collection and Application, \\ Guangzhou 510070, Guangdong, China
}

* Author to whom correspondence should be addressed; E-Mail: shiqingshan@hotmail.com; Tel.: +86-20-8713-7652; Fax: +86-20-8713-7650.

Academic Editor: Ester Boix

Received: 29 July 2015 / Accepted: 31 August 2015 / Published: 9 September 2015

\begin{abstract}
Antimicrobial agents target a range of extra- and/or intracellular loci from cytoplasmic wall to membrane, intracellular enzymes and genetic materials. Meanwhile, many resistance mechanisms employed by bacteria to counter antimicrobial agents have been found and reported in the past decades. Based on their spatially distinct sites of action and distribution of location, antimicrobial resistance mechanisms of bacteria were categorized into three groups, coined the three lines of bacterial defense in this review. The first line of defense is biofilms, which can be formed by most bacteria to overcome the action of antimicrobial agents. In addition, some other bacteria employ the second line of defense, the cell wall, cell membrane, and encased efflux pumps. When antimicrobial agents permeate the first two lines of defense and finally reach the cytoplasm, many bacteria will make use of the third line of defense, including alterations of intracellular materials and gene regulation to protect themselves from harm by bactericides. The presented three lines of defense theory will help us to understand the bacterial resistance mechanisms against antimicrobial agents and design efficient strategies to overcome these resistances.
\end{abstract}


Keywords: antimicrobial agents; defense lines; resistance mechanism; action sites; new theory

\section{Introduction}

Antimicrobial agents such as antibiotics, disinfectants and preservatives have been widely used to control or kill microorganisms in the past and will continue to be in long-term use [1-3]. Generally, all natural, semi-synthetic or synthetic substances with capacity of slowing or inhibiting the growth and reproduction of microorganisms and even killing them can be regarded as antimicrobial agents. These agents exhibit a specific action mechanism whereby microbial metabolism and physiological processes are modified including translation, DNA replication and cell wall biosynthesis [4,5]. Correspondingly, various biological and molecular responses of bacteria may be developed in the presence of antimicrobial agents [6]. Based on published literatures and the guidelines of Clinical and Laboratory Standards Institute (CLSI), antimicrobial resistance can be defined as an ability of microorganisms to resist the effects of one or more antimicrobial agents that they are originally sensitive to [7]. The emergence of antimicrobial resistance has become a major threat to public health and even causes huge losses in agriculture and industry around the world [8,9]. Better understanding of the resistance mechanisms of bacteria to antimicrobial agents can therefore guide the use of existing agents with improved activity and develop more efficient new ones. Many resistance mechanisms for bacteria to combat antimicrobial agents have been found in the past decades [10-14]. General resistance mechanisms include alterations of target sites, limited diffusions or impermeabilities, enzymatic modifications, efflux pumps and genetic adaptations [11,15]. Moreover, different resistance mechanisms will be employed by one given bacterium to protect themselves from one given antimicrobial agent or different ones [16].

Bacterial resistance mechanisms can be categorized into different groups based on different criteria. For example, antimicrobial resistances can be classified into two broad groups according to the acquired modes of resistance for bacteria to antimicrobial agents, i.e., intrinsic and acquired [5,17]. In this review, we attempt to address the general mechanisms that underlie the development of bacterial resistances to antimicrobial agents and categorize bacterial resistance mechanisms into three groups (namely three lines of defense) according to their sites of action of resistance (Figure 1): the first line of defense is bacterial biofilms; the cell wall, cell membrane and encased efflux pumps consist of the second line of defense; and, when bactericides ultimately get into the bacterial cells, intracellular biochemistry and genetic responses play an important role in resistances and are considered as the third line of defense. Developing these defense line theories will help us to more clearly understand the main resistance mechanisms of bacteria to overcome antimicrobial agents. 


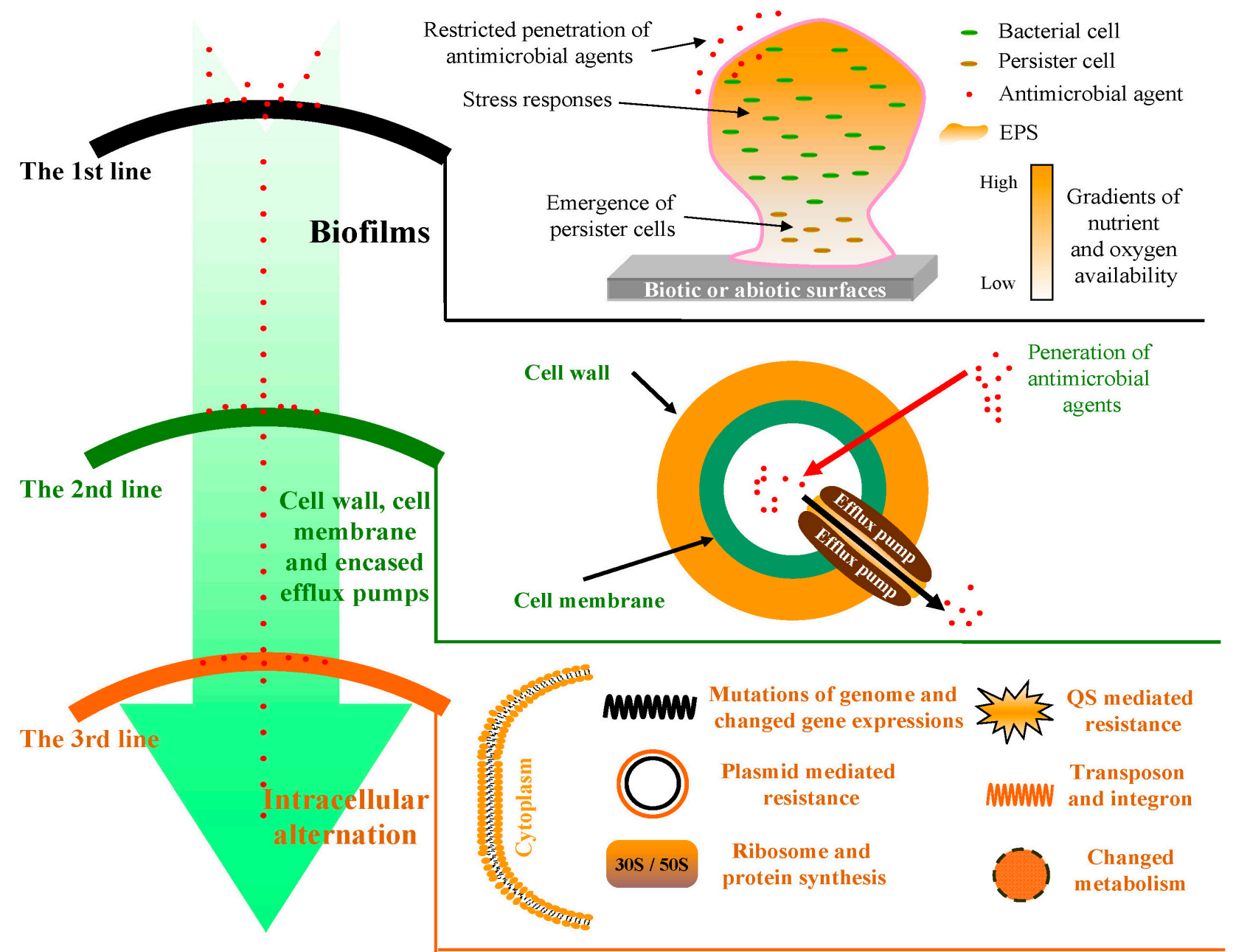

Figure 1. Simplified diagram summarizing the mechanisms of the three defense lines of resistance to antimicrobial agents for bacteria. There are three lines of defense for bacterial cells to overcome death by antimicrobial agents. The first defense line is bacterial biofilms, which limits the penetration of antimicrobial agents. The cell wall, cell membrane and the encased efflux pumps construct the second defense line to limit the absorbance or elevate the excretion of antimicrobial agents. When antimicrobial agents enter the bacterial cells, they meet the third line of defense, involving the alteration of target sites, regulation of gene expression and production of certain enzymes.

\section{The First Line of Defense: Bacterial Biofilms}

Biofilms are defined as a thin layer of microbial communities adhered to each other on organic or inorganic surfaces and enclosed by their secreted matrices of extracellular polymeric substance (EPS) $[18,19]$. It has been accepted that microorganisms live as a mode of biofilms but not solitary entities during most of its microbial life [20]. Biofilms formation can trigger serious environmental problems such as biofouling and dozens of human infections such as cystic fibrosis and urinary catheter cystitis [20-22]. When bacterial cells attach to a solid biotic or abiotic surface, they will gradually produce hydrated EPS and finally form the typical spatial structures of biofilms [13,23,24]. Typical biofilms development includes several stages, from the initial attachment of bacterial cells to maturation, 
as well as the final dispersion of biofilms $[18,25]$. Biofilms formation not only provides a protected mode of growth for bacterial cells to survive in hostile environments but also increase resistance level of bacteria to antimicrobial agents [26]. Although several mechanisms have been proposed to explain increased resistance to antimicrobial agents in bacterial biofilms, it is becoming obvious that only a combination of multi-factorial mechanisms or a collective resistance mechanism could interpret these resistances observed in biofilms communities [23,27].

\subsection{Restricted Penetration of Antimicrobial Agents}

Compared with planktonic cells, one of the distinguishing characteristics of biofilms is the production of EPS [24,28]. The EPS matrix of biofilms can limit and even prevent the transport of antimicrobial agents to the cells by either reacting with the bactericides, or sorption, or electrostatic and hydrophobic interactions, or size exclusion, or degradation of biocides [29,30]. The binding of antimicrobial agents to the protective EPS matrix will delay the time for antimicrobial agents to reach bacterial cells, resulting in the increased resistance level observed in biofilms [7,31]. As measured by a chlorine-detecting microelectrode, a commonly used disinfectant of chlorine did not reach higher than one fifth of the bulk media's concentration within a mixed biofilms formed by Klebsiella pneumoniae and Pseudomonas aeruginosa [32]. The penetration rates of amikacin and gentamicin were slower when penetrating through $P$. aeruginosa biofilm than piperacillin and imipenem [33]. Meanwhile, it has been observed that thick biofilms presented as a more efficient barrier than thin biofilms in delaying the penetration of antimicrobial agents [34].

Although the binding of antimicrobial agents to the possible reaction sites present in the EPS of biofilms can limit the transport of antimicrobials, unhindered delivery to the cells would resume when all sites in the matrix have been bound [23]. It has been reported that the biofilms formed by Staphylococcus epidermidis allow for the diffusion of rifampicin and vancomycin across the membrane, which implies that these antibiotics can efficiently penetrate biofilms [35]. More recent research has revealed that the biofilms of Burkholderia pseudomallei played a role as a diffusion barrier for ceftazidime and imipenem but not for trimethoprim or sulfamethoxazole [36]. The above evidence implies that the resistance mechanisms of biofilms to antimicrobial agents cannot be completely explained by the limitation of diffusion by EPS, but it does represent an initial barrier that can delay antimicrobial penetration.

\subsection{Physiological Gradients}

Microscale gradients in nutrient concentrations or growth factors are another well-known feature of biofilms [37]. There is a possible anaerobic condition in the microenvironment of biofilms because oxygen concentration is limited in the center of biofilms compared with at the surface [18]. The response of bacterial cells located in different places within a biofilm community to antimicrobial agents can greatly vary [38]. When bacterial cells grow in biofilms, growth will slow or stop due to a limited nutrient environment, which is generally accompanied by an increase in resistance to antimicrobial agents [21]. Only the upper metabolically active cells in $P$. aeruginosa biofilms could be effectively killed by fluoroquinolones and tetracycline [39]. On the contrary, the deeper slow-growing cells but not the actively growing cells that acquired adaptive resistance mediated by the pmr operon and the 
mexAB-oprM genes could be eradicated by an antimicrobial compound of lipopeptide colistin [39]. Because of limited nutrient availability, protein synthesis and metabolic activity in biofilms are also stratified, which is another explanation for the increased resistance of biofilms to antimicrobial agents [40,41]. In addition, Evans and colleagues reported that there were significant differences in resistance to ciprofloxacin between $P$. aeruginosa biofilms and planktonic cells at fast growth rates but not at slow growth rates, which indicated that only a reduction in growth rate could not completely explain all resistance mechanisms in biofilms to antimicrobial agents [42].

\subsection{Persistence}

Any given cells in biofilms live in a highly protected phenotypic state, grow at a different rate, and differentiate similar to spore formation [43]. A spore-like biofilm cell state (namely persistence) contributes significantly to the reduced susceptibility of biofilms to antimicrobial agents and provides a powerful genetic explanation for the resistance mechanisms in biofilms [43-45]. Indeed, it has been reported that the most significant resistance mechanism in $S$. epidermidis biofilms is that there are a large number of persister subpopulations in its biofilms [45]. Meanwhile, most of the population in biphasic biofilms is rapidly killed but a fraction of the cells are unaffected even by prolonged antibiotic treatment which is in support of the above hypothesis of persistence [46]. Persister cells cannot be affected by inhibitory concentrations of antimicrobial agents, and exhibit the ability to overcome stressful conditions, likely due to transcriptional programming [44].

\subsection{General Stress Response}

An efficient stress response system has been constructed by bacterial cells to deal with harmful environmental conditions [47]. These adaptive responses also contribute to resistance mechanisms in biofilms. Bacteria utilize a distinct subfamily of extracytoplasmic function (ECF) sigma factors to regulate extra cytoplasmic function and to serve as bacterial transcriptional regulators in the response to various stresses [48,49]. The ECF mutants (PGN_0274 and PGN_1740) of Porphyromonas gingivalis strain 33277 had increased biofilm formation compared with the wild-type [50]. Similar results were also found in a previous study conducted by another group. Inactivation of ECF-10 encoded by PP4553 in Pseudomonas putida KT2440 resulted in enhanced formation of biofilms after $24 \mathrm{~h}$ of incubation and two- to four-fold increased antibiotic resistance to quinolone, $\beta$-lactam, sulfonamide, and chloramphenicol antibiotics [51]. A comparative transcriptomic analysis was performed to identify differentially expressed genes during biofilms growth of $P$. aeruginosa [52]. The results showed that regulons associated with Anr-mediated hypoxia stress, RpoS-regulated stationary phase growth, and osmotic stresses were up-regulated in the biofilms and significantly enriched. The abilities of mutant strains deficient in rpoS, relAspoT, or anr to form biofilms were reduced when exposed to ciprofloxacin. These results suggested that multiple genes controlled by overlapping starvation or stress responses contributed to the protection of $P$. aeruginosa biofilms from ciprofloxacin [52].

As shown above, there are complex resistance mechanisms in bacterial biofilms so that it is quite difficult to diminish or eradicate them. However, some traditional and novel approaches used to control biofilms have been proposed in the past decades [53]. Combinations of tobramycin and clarithromycin have shown reasonable success in clearing $P$. aeruginosa pulmonary biofilm infections [54]. 
Meanwhile, combinations of peptide 1018 and some antibiotics such as ciprofloxacin decreased the concentration of antibiotic required to decrease initial biofilms formation and trigger cell death in mature biofilms. These findings suggested that treatment with the peptide represented a novel strategy to potentiate antibiotic activity against initial and mature biofilms formed by multidrug-resistant pathogens [55]. In addition to antibiotics, a variety of non-chemical substances were also developed to combat bacterial biofilms. D-amino acid can be used to inhibit biofilm formation by Staphylococcus aureus or P. aeruginosa through causing the release of amyloid fibers that linked cells in the biofilm together [56]. Based on a better understanding of the genetic basis of biofilm formation and development, conserved intracellular signals and regulators might be manipulated and used to control biofilms [57]. A great number of gene manipulation methods have been employed to induce biofilms dispersal [58-60]. More detailed approaches or strategies to combat bacterial biofilms could be found in the corresponding reviews [57,61]. Furthermore, we believe that more and more physiological, biochemical or molecular methods can be exploited to conquer biofilms and its resistances.

\section{The Second Line of Defense: Bacterial Cell Wall and Cell Membrane}

In order to exert their antibacterial activity, a wide variety of antimicrobial agents must attain a sufficiently high concentration at intracellular target sites. In order to reach their target site(s), they have to traverse the bacterial cell wall and membrane, which are crucial for maintaining cell shape and exchanging nutrients or signaling molecules. At the same time, the cell wall and membrane are also important targets for many antimicrobial compounds, including $\beta$-lactams, glycopeptides, fosfomycin, daptomycin, polymyxin, and ionophore antibiotics. A change in cell wall or membrane conformations or limited penetration of antimicrobial agents through these two physical barriers may induce the emergence of resistance. Moreover, restricting access or efficiently removing the antimicrobial agents by efflux pumps that are encased in the cell wall and membrane also contribute to increased levels of resistance. Hence, the cell wall, membrane and encased efflux pumps constitute the second line of defense for bacteria in combating antimicrobial agents.

\subsection{Cell Wall}

The bacterial cell wall is responsible for the maintenance of cell shape as well as other important functions [62,63]. Compared with parental cell walls, the peptidoglycan of a highly vancomycin-resistant mutant of $S$. aureus exhibited a significantly lower degree of cross-linkage. This observation and the results of vancomycin-binding studies suggested that alterations in the structural organization of the mutant cell walls blocked access of the vancomycin molecules to wall biosynthesis sites [64]. Resistance to glycopeptides such as vancomycin and teicoplanin derives from the synthesis of abnormal pentapeptide precursors, where precursors posses altered termini (e.g., D-Ala-D-lactate or D-Ala-D-ser) and a lower affinity for glycopeptides [65]. $\beta$-Lactams can block the transpeptidase and transglycosylase cross-linking enzymes in the peptidoglycan layer of cell walls [66]. Bacteria make use of two main strategies for protection against $\beta$-lactams: alteration in Penicillin-Binding Proteins (PBPs), which reduces the affinity of $\beta$-lactams for action sites, and production of $\beta$-lactamases, which hydrolyzes the ring of $\beta$-lactams rendering the molecule inactive [66-69]. 


\subsection{Cell Membrane}

Around the inside of the cell wall is a bacterial cell membrane, which works as a selective filter that allows or restricts cell permeation of substances, including antimicrobial agents, in or out of the cell. Membrane-active antimicrobial agents include multi-targeted lipopeptide daptomycin, peptidic antibiotics such as colistin and polymyxin B, and the ionophore antibiotics monensin and salinomycin [70]. The outer cell membrane of $P$. aeruginosa presents a significant permeability barrier to the penetration and excluding of antimicrobial molecules, which can lead to the occurrence of bacterial resistance [71]. Small hydrophilic antibiotics such as $\beta$-lactams and quinolones can only cross the outer membrane by passing through the aqueous channels provided by porin proteins. An outer membrane protein (OMP, $35 \mathrm{kDa}$ ) was found in wild-type (WT) cells of $P$. aeruginosa but not in isothiazolone-resistant cells. Therefore, it was proposed that this protein was the channel utilized by isothiazolone to transverse the cell membrane [72]. Furthermore, it was also found that each of the methylchloroisothiazolone (MCI)-resistant isolates of $P$. aeruginosa lacked a $42 \mathrm{kDa}$ protein, which is believed to be a porin known as OprD when compared with MCI-sensitive isolates. These findings reveal that the outer membrane can act as a permeability barrier, allowing for MCI resistance [73]. In addition, there were also some differences in OMP profiles between an isothiazolone-resistant strain of Burkholderia cepacia BC-IR induced from WT, and an isolated strain of B. cepacia BC-327 separated from industrial contamination samples [74] suggesting that different bacteria obtained from different sources may make use of different OMPs to exhibit their resistances.

\subsection{Multi-Drug Efflux Pumps}

Bacterial efflux systems are able to transport a wide variety of antimicrobial agents with different structures conferring multi-drug resistance (MDR) [75]. Generally, bacterial efflux pumps have been classified into two groups based on the energy source used by the pump [76-78]. The primary group includes the ATP (adenosine triphosphate)-binding cassette (ABC) super-family which uses the energy of ATP binding and hydrolysis for efflux; the secondary group includes the multidrug and toxic compound extrusion (MATE) family, the major facilitator super-family (MFS), the resistance-nodulation-division (RND) family, and the small multidrug resistance (SMR) family, all of which use the energy of the electrochemical potential of the membrane to power efflux [75,78-80]. Except for the RND super-family, which is only found in Gram-negative bacteria, efflux systems of the other four families are widely distributed in both Gram-positive and -negative bacteria [81]. It has been observed that the resistance of many bacteria to antimicrobial agents mainly developed by means of activation of efflux pumps [82]. The AcrAB/TolC system, comprised of an inner membrane transporter AcrB, an outer membrane protein channel TolC, and a periplasmic adaptor protein AcrA, is one of the most well-characterized efflux system in Gram-negative bacteria such as Escherichia coli $[83,84]$. Meanwhile, the compositional stoichiometry of this pump is 3:6:3 (AcrB:AcrA:TolC) [85]. When $\mathrm{Acr} A \mathrm{~B} / \mathrm{TolC}$ system is activated, the linker protein AcrA firstly fold on itself resulting in close contact of the AcrB and TolC proteins. Then, an exit path is provided from the inside to the outside of the cell so that antimicrobial agents can be pumped out through this channel $[83,86,87]$. More recently, a novel G288D substitution in AcrB of standard E. coli and Salmonella strains was found to have contributed to 
the resistance to ciprofloxacin [88]. In addition, four multidrug RND efflux systems of mexAB-oprM, mexCD-OprJ, mexEF-oprN, and mexXY-oprM are significant for clinically relevant resistance in P. aeruginosa $[78,89,90]$. Each above efflux system has its substrate specificities for antimicrobial agents. For example, extrusion of aminoglycosides and a group of the $\beta$-lactams is specific to MexXY-OprM and MexAB-OprM, respectively [91,92]. Furthermore, MexCD-OprJ can extrude novobiocin, cefsulodin, and flomoxef [91]. The up-regulation of MexCD-OprJ correlates with an increased resistance to ciprofloxacin, cefepime, chloramphenicol, or norfloxacin in $P$. aeruginosa [93,94]. In summary, efflux pump proteins contribute to the intrinsic and acquired resistance of $P$. aeruginosa through the multidrug active efflux process $[90,95]$. Besides the well-studied efflux pumps above, new pumps, such as KexD in Klebsiella pneumoniae [96] and MdeA in Streptococcus mutans [97], continue to be reported in the past few years. Taken together, the advances in understanding of efflux pumps and their resistance mechanisms will help us to propose a promising strategy and design efflux pump inhibitors for tackling multidrug resistance in bacteria $[78,98]$. Several natural and synthetic efflux pump inhibitors have been evaluated and are shown to reduce resistance in some studies. An inhibitor of RND transporters of 3,4-dibromopyrrole-2,5-dione decreased the MICs of seven antibiotics between 2- and 16-fold in over-expressing three archetype RND transporters (AcrAB-TolC, MexAB-OprM, and MexXY-OprM) strains [99]. Several naturally occurring indole alkaloids such as $\alpha$-yohimbine and its derivatives showed efflux pumps inhibitory potential and reduced MIC of tetracycline up to eight folds against a multidrug resistant clinical isolate of E. coli MDREC-KG4 [100].

In addition, efflux pumps have been also reported as one of the factors contributing to biofilms resistance to antimicrobial agents in several bacteria such as $P$. aeruginosa and E. coli [77]. Mutant strains of $P$. aeruginosa without the novel efflux pumps PA14 and PA1874 to PA1877 (PA1874-1877) become more sensitive to tobramycin, gentamicin and ciprofloxacin, specifically when these strains are grown as biofilms, which also provides an explanation for why these genes were important for biofilm resistance to antibiotics [101]. Deletion of the 16 operons encoding RND type efflux pumps demonstrated that RND-3, RND-8 and RND-9 protected biofilms against tobramycin in Burkholderia cenocepacia J2315 [102]. A more recently research has also demonstrated that efflux pumps contribute to glutaraldehyde resistance in P. fluorescens and P. aeruginosa biofilms based on RNA-Seq analysis and chemical inhibition assay [103]. However, some authors also found that the efflux pumps mentioned above did not contribute to the antibiotic-resistant phenotype and ciprofloxacin resistance in $P$. aeruginosa and $E$. coli biofilms, respectively [104,105], suggesting that there are other resistance mechanisms in the biofilms of $P$. aeruginosa and $E$. coli.

\section{The Third Line of Defense: Intracellular Alteration}

Although there are two lines of defense outside of the bacterial cells as described above, a variety of antimicrobial agents can still successfully penetrate into the cells and exert their activity. Inside the cells, antimicrobial agents may inhibit bacterial growth or kill bacteria through destroying metabolic systems and regular gene expressions. In response, bacterial cells will do their best to compete with antimicrobial agents including employing strategies like the alteration of target sites, production of antagonistic agents and regulation of gene expressions. All of the resistant strategies occurring inside of bacterial cells are considered as the third line of defense. 


\subsection{Bacterial Ribosome and Protein Synthesis}

Proteins within bacterial cells carry out a myriad of vital cell functions like catalyzing enzymatic reactions, sensing and passing on signals and making important physical structures. As such, inhibition of protein biosynthesis may lead to the death of bacteria. Antimicrobial agents target bacterial protein synthesis usually through interacting with ribosome and inhibiting its function. For example, the association of aminoacyl-tRNA with the bacterial $30 \mathrm{~S}$ ribosomal subunit can be prevented by tetracyclines resulting in the inhibition of bacterial protein synthesis [106,107]. Resistance to tetracyclines can also occur partly through the production of ribosomal protection proteins (RPPs) [108]. Aminoglycosides, such as streptomycin, can also bind to the $30 \mathrm{~S}$ bacterial subunit of ribosomes leading to inhibition of protein synthesis and final occurrence of resistance [109,110]. Moreover, the target site (i.e., ribosomal) mutations were also contributed to the resistance to aminoglycosides [111]. In contrast, chloramphenicol acts by binding to the $50 \mathrm{~S}$ ribosomal subunit to inhibit protein synthesis. Resistance to chloramphenicol has been described in part by the presence of chloramphenicol acetyltransferase (CAT), an enzyme that inactivates the drug [112]. The mode of action of macrolides is that they can bind to the bacterial $50 \mathrm{~S}$ ribosomal subunit thus inhibiting protein synthesis. The most common resistance mechanism to macrolides arises from methylation of an adenine residue in domain $\mathrm{V}$ of the 23S rRNA [113,114].

\subsection{Metabolic Pathway}

Bacteria may also develop resistance to an antimicrobial agent by increasing the production of a metabolite, which competes with the active site of the agents. It has been reported that $S$. aureus develops resistance to sulfonamide, an analogue to paraamino-benzoic acid (PABA), by increasing the production of PABA that would competitively displace sulfonamide [5]. This unusual increased production of PABA has been found to be due to mutations in the regulatory gene of the phosphate biosynthetic pathway [5].

\subsection{Quorum Sensing (QS) Systems}

One of significant mechanisms for bacterial communities to rapidly receive input from the environment and coordinately elicit an appropriate response under the stresses of antimicrobial agents is QS systems whose signaling requires an $N$-acyl-homoserine lactone (acyl-HSL) synthase (I protein) and a transcription factor with acyl-HSL-dependent activity (R protein) [115]. A signaling molecule served as an indicator of the population density would activate transcription of the genes encoding the $\mathrm{R}$ and $\mathrm{I}$ proteins under the help of the R protein-acyl-HSL complex so that a positive feedback regulatory mechanism was created [116]. In P. aeruginosa, a pathogenic QS bacterium, the transcription of genes encoding virulence factors would be also induced by activated R proteins in QS systems which signaling pathway become a target for the design of small molecule inhibitors [117,118]. A QS-deficient lasR rhlR mutant of $P$. aeruginosa is more sensitive to $\mathrm{H}_{2} \mathrm{O}_{2}$ because of the less production of catalase and NADPH-producing dehydrogenases [119].

Moreover, QS systems also contribute to the resistance mechanisms of biofilms. Two QS systems of LasR-LasI and RhlR-RhlI are global regulators of gene expression in the opportunistic pathogen 
P. aeruginosa [120]. A lasR-lasI mutant of $P$. aeruginosa lost its ability to form a biofilm with normal architecture, while lasI mutant biofilms exhibited increased sensitivity to sodium dodecyl sulfate (SDS) [121]. Similarly, P. aeruginosa biofilms with lasI and rhlI mutations display increased susceptibility to kanamycin compared to WT biofilms [122]. Meanwhile, the use of QS inhibitors (QSI) has been proposed as a potential antibiofilm strategy $[123,124]$.

\subsection{Genetic Regulation}

\subsubsection{DNA Synthesis}

Resistance to quinolones has been a problem ever since these drugs were introduced into clinical medicine. Quinolones are considered as inhibitors of the essential bacterial enzymes, DNA gyrase and DNA topoisomerase IV resulting in inhibition of DNA replication [125]. Similarly, chromosomal mutations in the subunits of DNA gyrase and topoisomerase IV also lead to the emergence of fluoroquinolones resistance [126].

\subsubsection{RNA Synthesis}

Rifampicin (Rif), a member of rifamycin family, can inhibit the bacterial RNA polymerase (RNAP) and is broadly used as an anti-tuberculosis agent to control bacterial pathogens. RNAP isolated from a Rif-resistant mutant of Mycobacterium smegmatis is less sensitive to Rif in vitro than WT strains, confirming that one mechanism of Rif resistance in mycobacteria is through alteration of RNAP [127]. Combined with biochemical analysis, the crystal structure of core RNAP complexed with Rif in Thermus aquaticus demonstrated that the path of the elongating RNA was directly blocked by Rif when the transcript becomes 2 to 3 nucleotide (nt) in length [128]. More recent literature has also shown that mutations in the rрoB gene encoding for the $\beta$-subunit of RNAP mainly contribute for Rif resistance [129]. Furthermore, resistance to aminoglycosides was also found to be related to RNA synthesis. Among Gram-negative pathogens such as Enterobacteriaceae and glucose-nonfermentative microbes, methylation of $16 \mathrm{~S}$ ribosomal RNA (rRNA) mediated by a newly recognized group of $16 \mathrm{~S}$ rRNA methylases has recently emerged as a new resistance mechanism against aminoglycosides [130].

\subsubsection{Plasmids}

A plasmid is a small, circular and double-stranded DNA molecule in bacterial cells. It is physically separated from chromosomal DNA and can replicate independently. Generally, plasmids can give the bacteria some survival advantages under certain conditions, such as the ability to survive in the presence of an antimicrobial agent [5]. A great number of enzymes encoded by plasmids can catalyze antimicrobial agents into a non-toxic form resulting in resistances. It has been found that the penicillinase plasmids, severed as a series of extrachromosomal resistance factors, carry determinants of resistance to penicillin and, in some cases, erythromycin in S. aureus [131]. Likely, it has been reported that heavy metal and formaldehyde resistance are mediated by enzymes, which are also encoded by corresponding plasmids [132]. Formaldehyde can be detoxified and reduced by a plasmid-encoded and constitutively expressed $\mathrm{NAD}^{+}$-gluthathione-dependent dehydrogenase in P. aeruginosa and P. putida [133]. Methylation of specific nucleotides in rRNA by methylases, such as erythromycin ribosome methylase $(\mathrm{ermC})[134,135]$ 
and chloramphenicol-florfenicol resistance (cfr) methyltransferase [136], which are carried on plasmids [137], to protect the drug-binding sites is one of the important means by which bacteria achieve resistance to several antimicrobial agents including macrolides, lincosamines, erythromycin, phenicols, pleuromutilins, and streptogramins [138]. The activity of $\beta$-lactamase encoded by plasmids usually induces high-level resistance of bacteria to broad-spectrum $\beta$-lactam antibiotics [139]. Both topoisomerase IV and DNA gyrase can be bound by pentapeptide repeat proteins (PRPs) encoded by plasmid-encoded quinolone resistance genes of $q n r$ group to protect the bacterial cells from the lethal action of quinolones [140-142]. The plasmid-borne fluoroquinolone-resistance determinants of qnr genes were widespreaded in Enterobacteriaceae. LexA is the central regulator of the SOS response to DNA damage. A LexA-binding site was found in the promoter region of all qnrB alleles and qnrB2 expression is regulated through the SOS response in a LexA/RecA-dependent manner [143]. Besides of the above evidences, the proteins or enzymes derived from plasmids also play a role at other defense lines. An IncH1 plasmid in a strain of Citrobacter freundii was found to encode a novel tripartite resistance nodulation division (RND) pump [144].

\subsubsection{Chromosome}

As we all know, the genetic information is stored in bacterial chromosome. Mutations of the target gene in bacterial chromosome can lead to the emergence of antibiotic resistance [145-147]. Many E. coli resistant strains from patients with uncomplicated urinary tract infections had mutations in $g y r A$, parC, parE, marOR, or acrR [148]. The SOS mutagenic response can be induced in the presence of non-lethal concentration of antimicrobial agents such as quinolones resulting in the emergence of resistance in E. coli [149]. In addition, resistance genes can horizontal transfer between two bacteria through transduction, conjugation and transformation so that the received strain gets the feature of resistance [146]. It has been demonstrated that comparative genomic analysis of S. suis strains with diverse drug-resistant phenotypes provided evidence that horizontal gene transfer is an important evolutionary force in shaping the genome of multi-drug-resistant strain of S. suis R61 [150]. Moreover, the horizontal dissemination of antibiotic resistance genes can be promoted by SOS response [151].

Transposon (also called jumping gene) is a genetic element that can move from one location in a chromosome to another location in the same or a different chromosome and thus alter the genetic constitution of the organism [152]. Many researchers have reported that transposon is also involved in bacterial resistance mechanisms. A Tn3-related transposon of Tn1546 confers glycopeptide resistance by synthesis of depsipeptide peptidoglycan precursors in Enterococcus faecium BM4147 [153]. Besides of Tn1546, other transposons including Tn1547, Tn1549, Tn916, conjugative transposons of the Tn916/Tn1545 family, Tn21 and a group of closely related transposons (the Tn21 family), also confer bacteria to resistant antimicrobial agents such as vancomycin and tetracycline [154-158].

Integrons are genetic units characterized by their ability to capture and incorporate gene cassettes by site-specific recombination resulting in antibiotics resistances [159-162]. All integrons are usually composed of three key elements necessary for the capture of exogenous genes: an intI gene; a primary recombination site (attI); and an outward- orientated promoter (Pc) [163]. It has been found that class I integrons contribute to antimicrobial resistance in Salmonella isolates and Stenotrophomonas maltophilia, respectively [164,165]. A new rifampin resistance gene arr-2, located on a gene cassette within a class I 
integron, was found in P. aeruginosa [166]. Furthermore, the SOS response controls a series of genes responsible for DNA damage repair. A variety of studies has proved that the SOS response controls integron recombination and promotes antibiotic resistance development $[167,168]$.

In addition, there might be a lot of genes (not only one or two genes) that contributes to the resistance mechanisms in bacteria. The conception of resistome was proposed by Gerard D. Wright for the collection of all the antibiotic resistance genes and their precursors in both pathogenic and non-pathogenic bacteria [169]. In the latest update, silent and proto-resistance genes were also included into the theoretical framework of the resistome [170]. This resistome would indirectly or directly induce the resistance mechanisms in bacteria. A comprehensive $P$. aeruginosa PA14 mutant library was constructed and screened for identifying genes involved in resistance to polymyxin B in this strain. Among the susceptible mutants, a significant number carried transposon insertions in lipopolysaccharide (LPS)-related genes ( galU, lptC, wapR, and ssg). A decrease in the presence and/or inducibility of aminoarabinose-modified lipid A species provided an additional explanation for the supersusceptible phenotype of these mutants [171]. Complex ciprofloxacin resistome of more than 100 genes in $P$. aeruginosa PA14 was also screened using a mutant library [172]. In addition to polymyxin B and ciprofloxacin, the intrinsic resistome of $P$. aeruginosa to $\beta$-lactams was also investigated using a comprehensive library of transposon-tagged insertion mutants. It was found that 37 loci in the chromosome of $P$. aeruginosa contributed to its intrinsic resistance [173].

\section{Conclusions}

In summation, bacteria build three main lines of defense at spatially distinct locations to protect themselves against antimicrobial agents (Figure 1). Firstly, most bacteria will live in the form of biofilms to increase their resistance levels to antimicrobial compounds through specific resistance mechanisms, including restricted penetration of antimicrobial agents, alteration of metabolic rates and gene regulations and formation of persister cells. Secondly, antimicrobial agents have to enter cells via the cell wall and membrane to exert their activity. Mutations that result in alterations of the cell wall and membrane can render the cells resistant to an antibiotic. Meanwhile, the efflux pumps encased in the cell wall and membrane also contribute to the resistance of some antimicrobial agents by pumping them out of the bacterial cells. Thirdly, even when antimicrobial agents successfully get inside the bacterial cells, they still have to remain stable and accumulate at the target sites to inhibitory concentrations. In some situations, the antibiotic requires activation and must traverse to its target(s) in order to exert antimicrobial activity. Mutations that result in changes of target sites and gene expressions, and production of quenchers against the antimicrobial agents all enhance resistance levels. All respective resistance cases and some corresponding substances, proteins or genes mentioned in this review are also summarized in Table 1. For a given antimicrobial agent, it has to prevail against multiple lines of defense for successful antimicrobial action, where two or three lines of defense may work simultaneously. At the same time, for a given item in a defense line, its function may exhibit at other lines. For example, the encoded products by plasmids can play a role in both intracellular and extracellular cells. In addition, collective antibiotic resistance was also proposed in recent years. In any case, the three main bacterial lines of defense against antimicrobials theory categorized by their spatially distinct sites of action and 
distribution will help us to rapidly and clearly understand and conceptualize the predominant antibiotic resistance mechanisms in bacteria and design reasonable strategies to overcome these resistances.

Table 1. Summary of the main resistance mechanisms in three lines of defense for bacteria to combat antimicrobial agents in this review.

\begin{tabular}{|c|c|c|c|}
\hline $\begin{array}{l}\text { Line of } \\
\text { Defense }\end{array}$ & Main Resistance Mechanisms & Related Substances, Proteins or Genes * & Representative References \\
\hline \multirow{4}{*}{$\begin{array}{l}\text { The } \\
\text { first }\end{array}$} & $\begin{array}{l}\text { Reduced penetration of } \\
\text { antimicrobial molecules }\end{array}$ & EPS & {$[32-34]$} \\
\hline & Physiological gradients & - & {$[21,39,40]$} \\
\hline & Formation of persister cells & - & {$[45,46]$} \\
\hline & General stress response & $r p o S, a n r$ & {$[51,52]$} \\
\hline \multirow{3}{*}{$\begin{array}{l}\text { The } \\
\text { second }\end{array}$} & Cell wall & Peptidoglycan & {$[64,65]$} \\
\hline & Cell membrane & Membrane proteins & {$[72-74]$} \\
\hline & Action of efflux pumps & $\begin{array}{c}\text { AcrAB/TolC, MexAB-oprM, } \\
\text { MexCD-OprJ, MexEF-oprN, MexXY-oprM }\end{array}$ & {$[87,88,91,93-97,101-103]$} \\
\hline \multirow{10}{*}{$\begin{array}{l}\text { The } \\
\text { third }\end{array}$} & Ribosome and protein synthesis & RPPs & {$[107,109,111-114]$} \\
\hline & $\begin{array}{l}\text { Increasing the production of a } \\
\text { metabolite }\end{array}$ & PABA & {$[5]$} \\
\hline & Quorum sensing (QS) systems & LasR-LasI, RhlR-RhlI & {$[119,121,122]$} \\
\hline & DNA synthesis & DNA gyrase, topoisomerase IV & {$[125,126]$} \\
\hline & RNA synthesis & $\begin{array}{l}\text { RNAP, } \\
\text { rRNA methylases }\end{array}$ & {$[128-130]$} \\
\hline & Plasmid mediated resistance & erm $C, c f r, \beta$-lactamase, $q n r$ & {$[131,133,135-140,142,144]$} \\
\hline & $\begin{array}{l}\text { Mutations of the target gene in } \\
\text { bacterial chromosome }\end{array}$ & gyrA, parC, parE, marOR, acrR & {$[148]$} \\
\hline & Transposon & - & {$[153,154-156]$} \\
\hline & Integrons & intI, attI, Pc, arr-2 & {$[164-166]$} \\
\hline & Resistome & - & {$[171-173]$} \\
\hline
\end{tabular}

* The listed cases represent only a part of examples in a given resistance mechanism, not for all.

\section{Acknowledgments}

Financial support was provided by the Cooperation Projects of Foshan City and Chinese Academy (No. 2012HY100115), Natural Science Foundation of Guangdong Province (No. 2015A030313713) and National Natural Science Foundation of China (No. 31500036).

\section{Author Contributions}

Gang Zhou conceived the idea and wrote the manuscript; Qing-Shan Shi, Xiao-Mo Huang, and Xiao-Bao Xie critically reviewed the manuscript and provided many suggestions; All authors approved the final manuscript.

\section{Conflicts of Interest}

The authors declare no conflict of interest. 


\section{References}

1. Reichel, M.; Schlicht, A.; Ostermeyer, C.; Kampf, G. Efficacy of surface disinfectant cleaners against emerging highly resistant Gram-negative bacteria. BMC Infect. Dis. 2014, 14, 292, doi:10.1186/1471-2334-14-292.

2. Zhang, J.; Chen, Y.P.; Miller, K.P.; Ganewatta, M.S.; Bam, M.; Yan, Y.; Nagarkatti, M.; Decho, A.W.; Tang, C. Antimicrobial metallopolymers and their bioconjugates with conventional antibiotics against multidrug-resistant bacteria. J. Am. Chem. Soc. 2014, 136, 4873-4876.

3. Altman, S. Antibiotics present and future. FEBS Lett. 2014, 588, 1-2.

4. Lima, T.B.; Pinto, M.F.S.; Ribeiro, S.M.; de Lima, L.A.; Viana, J.C.; Júnior, N.G.; de Souza Cândido, E.; Dias, S.C.; Franco, O.L. Bacterial resistance mechanism: What proteomics can elucidate. FASEB J. 2013, 27, 1291-1303.

5. Elufisan, T.O.; Oyedara, O.O.; Oyelade, B. Updates on microbial resistance to drugs. Afr. J. Microbiol. Res. 2012, 6, 4833-4844.

6. Morita, Y.; Tomida, J.; Kawamura, Y. Responses of Pseudomonas aeruginosa to antimicrobials. Front. Microbiol. 2014, 4, 422, doi:10.3389/fmicb.2013.00422.

7. Cloete, T.E. Resistance mechanisms of bacteria to antimicrobial compounds. Int. Biodeterior. Biodegrad. 2003, 51, 277-282.

8. Hampton, T. Report reveals scope of US antibiotic resistance threat. J. Am. Med. Assoc. 2013, 310, 1661-1663.

9. Waters, A.E.; Contente-Cuomo, T.; Buchhagen, J.; Liu, C.M.; Watson, L.; Pearce, K.; Foster, J.T.; Bowers, J.; Driebe, E.M.; Engelthaler, D.M.; et al. Multidrug-resistant Staphylococcus aureus in US meat and poultry. Clin. Infect. Dis. 2011, 52, 1227-1230.

10. McDonnell, G.; Russell, A.D. Antiseptics and disinfectants: Activity, action, and resistance. Clin. Microbiol. Rev. 1999, 12, 147-179.

11. Blair, J.M.A.; Webber, M.A.; Baylay, A.J.; Ogbolu, D.O.; Piddock, L.J.V. Molecular mechanisms of antibiotic resistance. Nat. Rev. Microbiol. 2015, 13, 42-51.

12. Yeaman, M.R.; Yount, N.Y. Mechanisms of antimicrobial peptide action and resistance. Pharmacol. Rev. 2003, 55, 27-55.

13. Høiby, N.; Bjarnsholt, T.; Givskov, M.; Molin, S.; Ciofu, O. Antibiotic resistance of bacterial biofilms. Int. J. Antimicrob. Agents 2010, 35, 322-332.

14. Poole, K. Efflux-mediated antimicrobial resistance. J. Antimicrob. Chemother. 2005, 56, $20-51$.

15. Poole, K. Mechanisms of bacterial biocide and antibiotic resistance. J. Appl. Microbiol. 2002, 92, 55S-64S.

16. Poole, K. Pseudomonas aeruginosa: Resistance to the max. Front. Microbiol. 2011, 2, 65, doi:10.3389/fmicb.2011.00065.

17. Olaitan, A.O.; Morand, S.; Rolain, J.M. Mechanisms of polymyxin resistance: Acquired and intrinsic resistance in bacteria. Front. Microbiol. 2014, 5, 643, doi:10.3389/fmicb.2014.00643.

18. Costerton, J.W.; Lewandowski, Z.; Caldwell, D.E.; Korber, D.R.; Lappin-Scott, H.M. Microbial biofilms. Annu. Rev. Microbiol. 1995, 49, 711-745.

19. Prakash, B.; Veeregowda, B.; Krishnappa, G. Biofilms: A survival strategy of bacteria. Curr. Sci. 2003, 85, 1299-1307. 
20. Hall-Stoodley, L.; Costerton, J.W.; Stoodley, P. Bacterial biofilms: From the natural environment to infectious diseases. Nat. Rev. Microbiol. 2004, 2, 95-108.

21. Costerton, J.; Stewart, P.S.; Greenberg, E. Bacterial biofilms: A common cause of persistent infections. Science 1999, 284, 1318-1322.

22. Flemming, H.C. Biofouling in water systems-cases, causes and countermeasures. Appl. Microbiol. Biotechnol. 2002, 59, 629-640.

23. Drenkard, E. Antimicrobial resistance of Pseudomonas aeruginosa biofilms. Microbes Infect. 2003, 5, 1213-1219.

24. Flemming, H.C.; Wingender, J. The biofilm matrix. Nat. Rev. Microbiol. 2010, 8, 623-633.

25. Stoodley, P.; Sauer, K.; Davies, D.; Costerton, J.W. Biofilms as complex differentiated communities. Annu. Rev. Microbiol. 2002, 56, 187-209.

26. Hoyle, B.D.; Costerton, J.W. Bacterial resistance to antibiotics: The role of biofilms. Prog. Drug. Res. 1991, 37, 91-105.

27. Vega, N.M.; Gore, J. Collective antibiotic resistance: Mechanisms and implications. Curr. Opin. Microbiol. 2014, 21, 28-34.

28. Sutherland, I.W. The biofilm matrix-An immobilized but dynamic microbial environment. Trends Microbiol. 2001, 9, 222-227.

29. Abdallah, M.; Benoliel, C.; Drider, D.; Dhulster, P.; Chihib, N.E. Biofilm formation and persistence on abiotic surfaces in the context of food and medical environments. Arch. Microbiol. 2014, 196, 453-472.

30. Billings, N.; Millan, M.; Caldara, M.; Rusconi, R.; Tarasova, Y.; Stocker, R.; Ribbeck, K. The extracellular matrix component Psl provides fast-acting antibiotic defense in Pseudomonas aeruginosa biofilms. PLoS Pathog. 2013, 9, e1003526.

31. Jolivet-Gougeon, A.; Bonnaure-Mallet, M. Biofilms as a mechanism of bacterial resistance. Drug Discov. Today Technol. 2014, 11, 49-56.

32. De Beer, D.; Srinivasan, R.; Stewart, P.S. Direct measurement of chlorine penetration into biofilms during disinfection. Appl. Environ. Microbiol. 1994, 60, 4339-4344.

33. Shigeta, M.; Tanaka, G.; Komatsuzawa, H.; Sugai, M.; Suginaka, H.; Usui, T. Permeation of antimicrobial agents through Pseudomonas aeruginosa biofilms: A simple method. Chemotherapy 1997, 43, 340-345.

34. Cochran, W.L.; McFeters, G.A.; Stewart, P.S. Reduced susceptibility of thin Pseudomonas aeruginosa biofilms to hydrogen peroxide and monochloramine. J. Appl. Microbiol. 2000, 88, 22-30.

35. Dunne, W.; Mason, E.; Kaplan, S.L. Diffusion of rifampin and vancomycin through a Staphylococcus epidermidis biofilm. Antimicrob. Agents Chemother. 1993, 37, 2522-2526.

36. Pibalpakdee, P.; Wongratanacheewin, S.; Taweechaisupapong, S.; Niumsup, P.R. Diffusion and activity of antibiotics against Burkholderia pseudomallei biofilms. Int. J. Antimicrob. Agents 2012, 39, 356-359.

37. Serra, D.O.; Hengge, R. Stress responses go three dimensional—The spatial order of physiological differentiation in bacterial macrocolony biofilms. Environ. Microbiol. 2014, 16, 1455-1471.

38. Mah, T.F.C.; O’Toole, G.A. Mechanisms of biofilm resistance to antimicrobial agents. Trends Microbiol. 2001, 9, 34-39. 
39. Pamp, S.J.; Gjermansen, M.; Johansen, H.K.; Tolker-Nielsen, T. Tolerance to the antimicrobial peptide colistin in Pseudomonas aeruginosa biofilms is linked to metabolically active cells, and depends on the pmr and mexAB-oprM genes. Mol. Microbiol. 2008, 68, 223-240.

40. Werner, E.; Roe, F.; Bugnicourt, A.; Franklin, M.J.; Heydorn, A.; Molin, S.; Pitts, B.; Stewart, P.S. Stratified growth in Pseudomonas aeruginosa biofilms. Appl. Environ. Microbiol. 2004, 70, 6188-6196.

41. Keren, I.; Kaldalu, N.; Spoering, A.; Wang, Y.; Lewis, K. Persister cells and tolerance to antimicrobials. FEMS Microbiol. Lett. 2004, 230, 13-18.

42. Evans, D.; Allison, D.; Brown, M.; Gilbert, P. Susceptibility of Pseudomonas aeruginosa and Escherichia coli biofilms towards ciprofloxacin: Effect of specific growth rate. J. Antimicrob. Chemother. 1991, 27, 177-184.

43. Stewart, P.S.; William Costerton, J. Antibiotic resistance of bacteria in biofilms. Lancet 2001, 358, $135-138$.

44. Lewis, K. Multidrug tolerance of biofilms and persister cells. Curr. Top. Microbiol. Immunol. 2008, 322, 107-131.

45. Qu, Y.; Daley, A.J.; Istivan, T.S.; Rouch, D.A.; Deighton, M.A. Densely adherent growth mode, rather than extracellular polymer substance matrix build-up ability, contributes to high resistance of Staphylococcus epidermidis biofilms to antibiotics. J. Antimicrob. Chemother. 2010, 65, 1405-1411.

46. Brooun, A.; Liu, S.; Lewis, K. A dose-response study of antibiotic resistance in Pseudomonas aeruginosa biofilms. Antimicrob. Agents Chemother. 2000, 44, 640-646.

47. Stewart, P.S. Mechanisms of antibiotic resistance in bacterial biofilms. Int. J. Med. Microbiol. 2002, 292, 107-113.

48. Heimann, J.D. The extracytoplasmic function (ECF) $\varsigma$ factors. Adv. Microb. Physiol. 2002, 46, 47-110.

49. Bashyam, M.D.; Hasnain, S.E. The extracytoplasmic function $\varsigma$ factors: Role in bacterial pathogenesis. Infect. Genet. Evol. 2004, 4, 301-308.

50. Onozawa, S.; Kikuchi, Y.; Shibayama, K.; Kokubu, E.; Nakayama, M.; Inoue, T.; Nakano, K.; Shibata, Y.; Ohara, N.; Nakayama, K. Role of extracytoplasmic function sigma factors in biofilm formation of Porphyromonas gingivalis. BMC Oral Health 2015, 15, 4, doi:10.1186/1472-6831-15-4.

51. Tettmann, B.; Dötsch, A.; Armant, O.; Fjell, C.D.; Overhage, J. Knockout of extracytoplasmic function sigma factor ECF-10 affects stress resistance and biofilm formation in Pseudomonas putida KT2440. Appl. Environ. Microbiol. 2014, 80, 4911-4919.

52. Stewart, P.S.; Franklin, M.J.; Williamson, K.S.; Folsom, J.P.; Boegli, L.; James, G.A. Contribution of stress responses to antibiotic tolerance in Pseudomonas aeruginosa biofilms. Antimicrob. Agents Chemother. 2015, 59, 3838-3847.

53. Taylor, P.K.; Yeung, A.T.; Hancock, R.E. Antibiotic resistance in Pseudomonas aeruginosa biofilms: Towards the development of novel anti-biofilm therapies. J. Biotechnol. 2014, 191, 121-130.

54. Thellin, O.; Zorzi, W.; Jolois, O.; Elmoualij, B.; Duysens, G.; Cahay, B.; Streel, B.; Charif, M.; Bastin, R.; Heinen, E. In vitro approach to study the synergistic effects of tobramycin and clarithromycin against Pseudomonas aeruginosa biofilms using prokaryotic or eukaryotic culture media. Int. J. Antimicrob. Agents 2015, 46, 33-38. 
55. Reffuveille, F.; de la Fuente-Núñez, C.; Mansour, S.; Hancock, R.E. A broad-spectrum antibiofilm peptide enhances antibiotic action against bacterial biofilms. Antimicrob. Agents Chemother. 2014, 58, 5363-5371.

56. Kolodkin-Gal, I.; Romero, D.; Cao, S.; Clardy, J.; Kolter, R.; Losick, R. D-amino acids trigger biofilm disassembly. Science 2010, 328, 627-629.

57. Wood, T.K.; Hong, S.H.; Ma, Q. Engineering biofilm formation and dispersal. Trends Biotechnol. 2011, 29, 87-94.

58. Hong, S.H.; Hegde, M.; Kim, J.; Wang, X.; Jayaraman, A.; Wood, T.K. Synthetic quorum-sensing circuit to control consortial biofilm formation and dispersal in a microfluidic device. Nat. Commun. 2012, 3, 613, doi:10.1038/ncomms1616.

59. Ma, Q.; Yang, Z.; Pu, M.; Peti, W.; Wood, T.K. Engineering a novel c-di-GMP-binding protein for biofilm dispersal. Environ. Microbiol. 2011, 13, 631-642.

60. Hong, S.H.; Lee, J.; Wood, T.K. Engineering global regulator Hha of Escherichia coli to control biofilm dispersal. Microb. Biotechnol. 2010, 3, 717-728.

61. Beloin, C.; Renard, S.; Ghigo, J.M.; Lebeaux, D. Novel approaches to combat bacterial biofilms. Curr. Opin. Pharmacol. 2014, 18, 61-68.

62. Huang, K.C.; Mukhopadhyay, R.; Wen, B.; Gitai, Z.; Wingreen, N.S. Cell shape and cell-wall organization in Gram-negative bacteria. Proc. Natl. Acad. Sci. USA 2008, 105, 19282-19287.

63. Schaffer, C.; Messner, P. The structure of secondary cell wall polymers: How Gram-positive bacteria stick their cell walls together. Microbiology 2005, 151, 643-651.

64. Sieradzki, K.; Tomasz, A. Inhibition of cell wall turnover and autolysis by vancomycin in a highly vancomycin-resistant mutant of Staphylococcus aureus. J. Bacteriol. 1997, 179, 2557-2566.

65. Cetinkaya, Y.; Falk, P.; Mayhall, C.G. Vancomycin-resistant Enterococci. Clin. Microbiol. Rev. 2000, 13, 686-707.

66. Walsh, C. Molecular mechanisms that confer antibacterial drug resistance. Nature 2000, 406, $775-781$.

67. Bush, K. Proliferation and significance of clinically relevant $\beta$-lactamases. Ann. N. Y. Acad. Sci. 2013, 1277, 84-90.

68. Poole, K. Efflux pumps as antimicrobial resistance mechanisms. Ann. Med. 2007, 39, 162-176.

69. Zapun, A.; Contreras-Martel, C.; Vernet, T. Penicillin-binding proteins and $\beta$-lactam resistance. FEMS Microbiol. Rev. 2008, 32, 361-385.

70. Bayer, A.S.; Schneider, T.; Sahl, H.G. Mechanisms of daptomycin resistance in Staphylococcus aureus: Role of the cell membrane and cell wall. Ann. N. Y. Acad. Sci. 2013, 1277, 139-158.

71. Lambert, P. Mechanisms of antibiotic resistance in Pseudomonas aeruginosa. J. R. Soc. Med. 2002, 95, 22-26.

72. Brözel, V.S.; Cloete, T.E. Resistance of Pseudomonas aeruginosa to isothiazolone. J. Appl. Bacteriol. 1994, 76, 576-582.

73. Chapman, J.S.; Diehl, M.A.; Fearnside, K.B. Preservative tolerance and resistance. Int. J. Cosmet. Sci. 1998, 20, 31-39.

74. Zhou, G.; Shi, Q.; Ouyang, Y.; Chen, Y. Involvement of outer membrane proteins and peroxide-sensor genes in Burkholderia cepacia resistance to isothiazolone. World J. Microbiol. Biotechnol. 2014, 30, 1251-1260. 
75. Paulsen, I.T. Multidrug efflux pumps and resistance: Regulation and evolution. Curr. Opin. Microbiol. 2003, 6, 446-451.

76. Piddock, L.J. Clinically relevant chromosomally encoded multidrug resistance efflux pumps in bacteria. Clin. Microbiol. Rev. 2006, 19, 382-402.

77. Soto, S.M. Role of efflux pumps in the antibiotic resistance of bacteria embedded in a biofilm. Virulence 2013, 4, 223-229.

78. Blair, J.M.; Richmond, G.E.; Piddock, L.J. Multidrug efflux pumps in Gram-negative bacteria and their role in antibiotic resistance. Future Microbiol. 2014, 9, 1165-1177.

79. Piddock, L.J. Multidrug-resistance efflux pumps? Not just for resistance. Nat. Rev. Microbiol. 2006, 4, 629-636.

80. Putman, M.; van Veen, H.W.; Konings, W.N. Molecular properties of bacterial multidrug transporters. Microbiol. Mol. Biol. Rev. 2000, 64, 672-693.

81. Handzlik, J.; Matys, A.; Kieć-Kononowicz, K. Recent advances in multi-drug resistance (MDR) efflux pump inhibitors of Gram-positive bacteria $S$. aureus. Antibiotics 2013, 2, 28-45.

82. Jayaraman, R. Antibiotic resistance: An overview of mechanisms and a paradigm shift. Curr. Sci. 2009, 96, 1475-1484.

83. Yamaguchi, A.; Nakashima, R.; Sakurai, K. Structural basis of RND-type multidrug exporters. Front. Microbiol. 2015, 6, 327, doi:10.3389/fmicb.2015.00327.

84. Du, D.; Wang, Z.; James, N.R.; Voss, J.E.; Klimont, E.; Ohene-Agyei, T.; Venter, H.; Chiu, W.; Luisi, B.F. Structure of the AcrAB-TolC multidrug efflux pump. Nature 2014, 509, 512-515.

85. Janganan, T.K.; Bavro, V.N.; Zhang, L.; Matak-Vinkovic, D.; Barrera, N.P.; Venien-Bryan, C.; Robinson, C.V.; Borges-Walmsley, M.I.; Walmsley, A.R. Evidence for the assembly of a bacterial tripartite multidrug pump with a stoichiometry of 3:6:3. J. Biol. Chem. 2011, 286, 26900-26912.

86. Zgurskaya, H.I.; Weeks, J.W.; Ntreh, A.T.; Nickels, L.M.; Wolloscheck, D. Mechanism of coupling drug transport reactions located in two different membranes. Front. Microbiol. 2015, 6, 100, doi:10.3389/fmicb.2015.00100.

87. Murakami, S.; Nakashima, R.; Yamashita, E.; Matsumoto, T.; Yamaguchi, A. Crystal structures of a multidrug transporter reveal a functionally rotating mechanism. Nature 2006, 443, 173-179.

88. Blair, J.M.A.; Bavro, V.N.; Ricci, V.; Modi, N.; Cacciotto, P.; Kleinekathofer, U.; Ruggerone, P.; Vargiu, A.V.; Baylay, A.J.; Smith, H.E.; et al. AcrB drug-binding pocket substitution confers clinically relevant resistance and altered substrate specificity. Proc. Natl. Acad. Sci. USA 2015, 112, 3511-3516.

89. Poole, K. Multidrug efflux pumps and antimicrobial resistance in Pseudomonas aeruginosa and related organisms. J. Mol. Microbiol. Biotechnol. 2001, 3, 255-264.

90. Poole, K. Pseudomonas aeruginosa efflux pumps. In Microbial Efflux Pumps: Current Research; Yu, E.W., Zhang, Q., Brown, M.H., Eds.; Caister Academic Press: Norfolk, UK, 2013; pp. 175-206.

91. Masuda, N.; Sakagawa, E.; Ohya, S.; Gotoh, N.; Tsujimoto, H.; Nishino, T. Substrate specificities of MexAB-OprM, MexCD-OprJ, and MexXY-oprM efflux pumps in Pseudomonas aeruginosa. Antimicrob. Agents Chemother. 2000, 44, 3322-3327.

92. Morita, Y.; Tomida, J.; Kawamura, Y. MexXY multidrug efflux system of Pseudomonas aeruginosa. Front. Microbiol. 2012, 3, 408, doi:10.3389/fmicb.2012.00408. 
93. Jeannot, K.; Elsen, S.; Köhler, T.; Attree, I.; van Delden, C.; Plésiat, P. Resistance and virulence of Pseudomonas aeruginosa clinical strains overproducing the MexCD-OprJ efflux pump. Antimicrob. Agents Chemother. 2008, 52, 2455-2462.

94. Morita, Y.; Murata, T.; Mima, T.; Shiota, S.; Kuroda, T.; Mizushima, T.; Gotoh, N.; Nishino, T.; Tsuchiya, T. Induction of mexCD-oprJ operon for a multidrug efflux pump by disinfectants in wild-type Pseudomonas aeruginosa PAO1. J. Antimicrob. Chemother. 2003, 51, 991-994.

95. Li, X.Z.; Nikaido, H.; Poole, K. Role of mexA-mexB-oprM in antibiotic efflux in Pseudomonas aeruginosa. Antimicrob. Agents Chemother. 1995, 39, 1948-1953.

96. Ogawa, W.; Onishi, M.; Ni, R.T.; Tsuchiya, T.; Kuroda, T. Functional study of the novel multidrug efflux pump KexD from Klebsiella pneumoniae. Gene 2012, 498, 177-182.

97. Kim, D.K.; Kim, K.H.; Choi, E.J.; Joo, S.J.; Chung, J.M.; Son, B.Y.; Yum, J.H.; Kim, Y.M.; Kwon, H.J.; Kim, B.W.; et al. Gene cloning and characterization of MdeA, a novel multidrug efflux pump in Streptococcus mutans. J. Microbiol. Biotechnol. 2013, 23, 430-435.

98. Venter, H.; Mowla, R.; Ohene-Agyei, T.; Ma, S. RND-type drug efflux pumps from Gram-negative bacteria: Molecular mechanism and inhibition. Front. Microbiol. 2015, 6, 377.

99. Whalen, K.E.; Poulson-Ellestad, K.L.; Deering, R.W.; Rowley, D.C.; Mincer, T.J. Enhancement of antibiotic activity against multidrug-resistant bacteria by the efflux pump inhibitor 3, 4-dibromopyrrole-2, 5-dione isolated from a Pseudoalteromonas sp. J. Nat. Prod. 2015, 78, $402-412$.

100. Dwivedi, G.R.; Gupta, S.; Maurya, A.; Tripathi, S.; Sharma, A.; Darokar, M.P.; Srivastava, S.K. Synergy potential of indole alkaloids and its derivative against drug resistant Escherichia coli. Chem. Biol. Drug Des. 2015, doi:10.1111/cbdd.12613.

101. Zhang, L.; Mah, T.F. Involvement of a novel efflux system in biofilm-specific resistance to antibiotics. J. Bacteriol. 2008, 190, 4447-4452.

102. Buroni, S.; Matthijs, N.; Spadaro, F.; van Acker, H.; Scoffone, V.C.; Pasca, M.R.; Riccardi, G.; Coenye, T. Differential role of RND efflux pumps in antimicrobial drug resistance of sessile and planktonic Burkholderia cenocepacia cells. Antimicrob. Agents Chemother. 2014, 58, 7424-7429.

103. Vikram, A.; Bomberger, J.M.; Bibby, K.J. Efflux as a glutaraldehyde resistance mechanism in Pseudomonas fluorescens and Pseudomonas aeruginosa biofilms. Antimicrob. Agents Chemother. 2015, 59, 3433-3440.

104. De Kievit, T.R.; Parkins, M.D.; Gillis, R.J.; Srikumar, R.; Ceri, H.; Poole, K.; Iglewski, B.H.; Storey, D.G. Multidrug efflux pumps: Expression patterns and contribution to antibiotic resistance in Pseudomonas aeruginosa biofilms. Antimicrob. Agents Chemother. 2001, 45, 1761-1770.

105. Maira-Litran, T.; Allison, D.G.; Gilbert, P. An evaluation of the potential of the multiple antibiotic resistance operon (mar) and the multidrug efflux pump acrAB to moderate resistance towards ciprofloxacin in Escherichia coli biofilms. J. Antimicrob. Chemother. 2000, 45, 789-795.

106. Chopra, I.; Hawkey, P.; Hinton, M. Tetracyclines, molecular and clinical aspects. J. Antimicrob. Chemother. 1992, 29, 245-277.

107. Brodersen, D.E.; Clemons, W.M., Jr.; Carter, A.P.; Morgan-Warren, R.J.; Wimberly, B.T.; Ramakrishnan, V. The structural basis for the action of the antibiotics tetracycline, pactamycin, and hygromycin B on the 30S ribosomal subunit. Cell 2000, 103, 1143-1154. 
108. Thaker, M.; Spanogiannopoulos, P.; Wright, G.D. The tetracycline resistome. Cell. Mol. Life Sci. 2010, 67, 419-431.

109. Fritsche, T.R.; Castanheira, M.; Miller, G.H.; Jones, R.N.; Armstrong, E.S. Detection of methyltransferases conferring high-level resistance to aminoglycosides in Enterobacteriaceae from Europe, North America, and Latin America. Antimicrob. Agents Chemother. 2008, 52, 1843-1845.

110. Mingeot-Leclercq, M.P.; Glupczynski, Y.; Tulkens, P.M. Aminoglycosides: Activity and resistance. Antimicrob. Agents Chemother. 1999, 43, 727-737.

111. Springer, B.; Kidan, Y.G.; Prammananan, T.; Ellrott, K.; Böttger, E.C.; Sander, P. Mechanisms of streptomycin resistance: Selection of mutations in the 16S rRNA gene conferring resistance. Antimicrob. Agents Chemother. 2001, 45, 2877-2884.

112. Schwarz, S.; Kehrenberg, C.; Doublet, B.; Cloeckaert, A. Molecular basis of bacterial resistance to chloramphenicol and florfenicol. FEMS Microbiol. Rev. 2004, 28, 519-542.

113. Sulavik, M.C.; Houseweart, C.; Cramer, C.; Jiwani, N.; Murgolo, N.; Greene, J.; DiDomenico, B.; Shaw, K.J.; Miller, G.H.; Hare, R. Antibiotic susceptibility profiles of Escherichia coli strains lacking multidrug efflux pump genes. Antimicrob. Agents Chemother. 2001, 45, 1126-1136.

114. Monteiro, R.; Vitorino, R.; Domingues, P.; Radhouani, H.; Carvalho, C.; Poeta, P.; Torres, C.; Igrejas, G. Proteome of a methicillin-resistant Staphylococcus aureus clinical strain of sequence type ST398. J. Proteom. 2012, 75, 2892-2915.

115. Miller, M.B.; Bassler, B.L. Quorum sensing in bacteria. Annu. Rev. Microbiol. 2001, 55, 165-199.

116. Solano, C.; Echeverz, M.; Lasa, I. Biofilm dispersion and quorum sensing. Curr. Opin. Microbiol. 2014, 18, 96-104.

117. De Kievit, T.R.; Iglewski, B.H. Bacterial quorum sensing in pathogenic relationships. Infect. Immun. 2000, 68, 4839-4849.

118. Suga, H.; Smith, K.M., Molecular mechanisms of bacterial quorum sensing as a new drug target. Curr. Opin. Chem. Biol. 2003, 7, 586-591.

119. Garcia-Contreras, R.; Nunez-Lopez, L.; Jasso-Chavez, R.; Kwan, B.W.; Belmont, J.A.; Rangel-Vega, A.; Maeda, T.; Wood, T.K. Quorum sensing enhancement of the stress response promotes resistance to quorum quenching and prevents social cheating. ISME J. 2015, 9, 115-125.

120. Schuster, M.; Peter Greenberg, E. A network of networks: Quorum-sensing gene regulation in Pseudomonas aeruginosa. Int. J. Med. Microbiol. 2006, 296, 73-81.

121. Davies, D.G.; Parsek, M.R.; Pearson, J.P.; Iglewski, B.H.; Costerton, J.; Greenberg, E., The involvement of cell-to-cell signals in the development of a bacterial biofilm. Science 1998, 280, 295-298.

122. Shih, P.C.; Huang, C.T. Effects of quorum-sensing deficiency on Pseudomonas aeruginosa biofilm formation and antibiotic resistance. J. Antimicrob. Chemother. 2002, 49, 309-314.

123. Brackman, G.; Cos, P.; Maes, L.; Nelis, H.J.; Coenye, T. Quorum sensing inhibitors increase the susceptibility of bacterial biofilms to antibiotics in vitro and in vivo. Antimicrob. Agents Chemother. 2011, 55, 2655-2661.

124. Balaban, N.; Cirioni, O.; Giacometti, A.; Ghiselli, R.; Braunstein, J.B.; Silvestri, C.; Mocchegiani, F.; Saba, V.; Scalise, G. Treatment of Staphylococcus aureus biofilm infection by the quorum-sensing inhibitor RIP. Antimicrob. Agents Chemother. 2007, 51, 2226-2229. 
125. Drlica, K.; Zhao, X. DNA gyrase, topoisomerase IV, and the 4-quinolones. Microbiol. Mol. Biol. Rev. 1997, 61, 377-392.

126. Jacoby, G.A. Mechanisms of resistance to quinolones. Clin. Infect. Dis. 2005, 41, S120-S126.

127. Levin, M.E.; Hatfull, G.F. Mycobacterium smegmatis RNA polymerase: DNA supercoiling, action of rifampicin and mechanism of rifampicin resistance. Mol. Microbiol. 1993, 8, 277-285.

128. Campbell, E.A.; Korzheva, N.; Mustaev, A.; Murakami, K.; Nair, S.; Goldfarb, A.; Darst, S.A. Structural mechanism for rifampicin inhibition of bacterial RNA polymerase. Cell 2001, 104, 901-912.

129. Vranakis, I.; Goniotakis, I.; Psaroulaki, A.; Sandalakis, V.; Tselentis, Y.; Gevaert, K.; Tsiotis, G. Proteome studies of bacterial antibiotic resistance mechanisms. J. Proteom. 2014, 97, 88-99.

130. Doi, Y.; Arakawa, Y. 16S ribosomal RNA methylation: Emerging resistance mechanism against aminoglycosides. Clin. Infect. Dis. 2007, 45, 88-94.

131. Novick, R.P.; Roth, C. Plasmid-linked resistance to inorganic salts in Staphylococcus aureus. J. Bacteriol. 1968, 95, 1335-1342.

132. Foster, T.J. Plasmid-determined resistance to antimicrobial drugs and toxic metal ions in bacteria. Microbiol. Rev. 1983, 47, 361-370.

133. Kümmerle, N.; Feucht, H.H.; Kaulfers, P.M. Plasmid-mediated formaldehyde resistance in Escherichia coli: Characterization of resistance gene. Antimicrob. Agents Chemother. 1996, 40, 2276-2279.

134. Leclercq, R. Mechanisms of resistance to macrolides and lincosamides: Nature of the resistance elements and their clinical implications. Clin. Infect. Dis. 2002, 34, 482-492.

135. Lina, G.; Quaglia, A.; Reverdy, M.E.; Leclercq, R.; Vandenesch, F.; Etienne, J. Distribution of genes encoding resistance to macrolides, lincosamides, and streptogramins among staphylococci. Antimicrob. Agents Chemother. 1999, 43, 1062-1066.

136. Long, K.S.; Poehlsgaard, J.; Kehrenberg, C.; Schwarz, S.; Vester, B. The Cfr rRNA methyltransferase confers resistance to phenicols, lincosamides, oxazolidinones, pleuromutilins, and streptogramin a antibiotics. Antimicrob. Agents Chemother. 2006, 50, 2500-2505.

137. Zhang, W.J.; Xu, X.R.; Schwarz, S.; Wang, X.M.; Dai, L.; Zheng, H.J.; Liu, S. Characterization of the IncA/C plasmid pSCEC2 from Escherichia coli of swine origin that harbours the multiresistance gene cfr. J. Antimicrob. Chemother. 2014, 69, 385-389.

138. Liu, M.; Douthwaite, S. Activity of the ketolide telithromycin is refractory to Erm monomethylation of bacterial rRNA. Antimicrob. Agents Chemother. 2002, 46, 1629-1633.

139. Docquier, J.D.; Riccio, M.L.; Mugnaioli, C.; Luzzaro, F.; Endimiani, A.; Toniolo, A.; Amicosante, G.; Rossolini, G.M. IMP-12, a new plasmid-encoded metallo- $\beta$-lactamase from a Pseudomonas putida clinical isolate. Antimicrob. Agents Chemother. 2003, 47, 1522-1528.

140. Vetting, M.W.; Hegde, S.S.; Wang, M.; Jacoby, G.A.; Hooper, D.C.; Blanchard, J.S. Structure of QnrB1, a plasmid-mediated fluoroquinolone resistance factor. J. Biol. Chem. 2011, 286, 25265-25273.

141. Strahilevitz, J.; Jacoby, G.A.; Hooper, D.C.; Robicsek, A. Plasmid-mediated quinolone resistance: A multifaceted threat. Clin. Microbiol. Rev. 2009, 22, 664-689.

142. Tran, J.H.; Jacoby, G.A.; Hooper, D.C. Interaction of the plasmid-encoded quinolone resistance protein Qnr with Escherichia coli DNA gyrase. Antimicrob. Agents Chemother. 2005, 49, 118-125. 
143. Da Re, S.; Garnier, F.; Guérin, E.; Campoy, S.; Denis, F.; Ploy, M.C. The SOS response promotes qnrB quinolone - resistance determinant expression. EMBO Rep. 2009, 10, 929-933.

144. Dolejska, M.; Villa, L.; Poirel, L.; Nordmann, P.; Carattoli, A. Complete sequencing of an IncHI1 plasmid encoding the carbapenemase NDM-1, the ArmA 16S RNA methylase and a resistance-nodulation-cell division/multidrug efflux pump. J. Antimicrob. Chemother. 2013, 68, 34-39.

145. Alekshun, M.N.; Levy, S.B. Molecular mechanisms of antibacterial multidrug resistance. Cell 2007, 128, 1037-1050.

146. Džidić, S.; Šušković, J.; Kos, B. Antibiotic resistance mechanisms in bacteria: Biochemical and genetic aspects. Food Technol. Biotechnol. 2008, 46, 11-21.

147. Woodford, N.; Ellington, M.J. The emergence of antibiotic resistance by mutation. Clin. Microbiol. Infect. 2007, 13, 5-18.

148. Komp Lindgren, P.; Karlsson, A.; Hughes, D. Mutation rate and evolution of fluoroquinolone resistance in Escherichia coli isolates from patients with urinary tract infections. Antimicrob. Agents Chemother. 2003, 47, 3222-3232.

149. Dorr, T.; Lewis, K.; Vulic, M. SOS response induces persistence to fluoroquinolones in Escherichia coli. PLoS Genet. 2009, 5, e1000760.

150. Hu, P.; Yang, M.; Zhang, A.; Wu, J.; Chen, B.; Hua, Y.; Yu, J.; Chen, H.; Xiao, J.; Jin, M. Comparative genomics study of multi-drug-resistance mechanisms in the antibiotic-resistant Streptococcus suis R61 strain. PLoS ONE 2011, 6, e24988.

151. Beaber, J.W.; Hochhut, B.; Waldor, M.K. SOS response promotes horizontal dissemination of antibiotic resistance genes. Nature 2004, 427, 72-74.

152. Pray, L.A. Transposons: The jumping genes. Nat. Educ. 2008, 1, 204.

153. Arthur, M.; Molinas, C.; Depardieu, F.; Courvalin, P. Characterization of Tn1546, a Tn3-related transposon conferring glycopeptide resistance by synthesis of depsipeptide peptidoglycan precursors in Enterococcus faecium BM4147. J. Bacteriol. 1993, 175, 117-127.

154. Quintiliani, R.; Courvalin, P. Characterization of Tn1547, a composite transposon flanked by the IS16 and IS256-like elements, that confers vancomycin resistance in Enterococcus faecalis BM4281. Gene 1996, 172, 1-8.

155. Garnier, F.; Taourit, S.; Glaser, P.; Courvalin, P.; Galimand, M. Characterization of transposon Tn1549, conferring VanB-type resistance in Enterococcus spp. Microbiology 2000, 146, 1481-1489.

156. Dong, D.; Chen, X.; Jiang, C.; Zhang, L.; Cai, G.; Han, L.; Wang, X.; Mao, E.; Peng, Y. Genetic analysis of Tn916-like elements conferring tetracycline resistance in clinical isolates of Clostridium difficile. Int. J. Antimicrob. Agents 2014, 43, 73-77.

157. Roberts, A.P.; Mullany, P. Tn916-like genetic elements: A diverse group of modular mobile elements conferring antibiotic resistance. FEMS Microbiol. Rev. 2011, 35, 856-871.

158. Liebert, C.A.; Hall, R.M.; Summers, A.O. Transposon Tn21, flagship of the floating genome. Microbiol. Mol. Biol. Rev. 1999, 63, 507-522.

159. Gillings, M.R. Integrons: Past, present, and future. Microbiol. Mol. Biol. Rev. 2014, 78, 257-277.

160. Mazel, D. Integrons: Agents of bacterial evolution. Nat. Rev. Microbiol. 2006, 4, 608-620.

161. Ravi, A.; Avershina, E.; Ludvigsen, J.; L’Abée-Lund, T.M.; Rudi, K. Integrons in the intestinal microbiota as reservoirs for transmission of antibiotic resistance genes. Pathogens 2014, 3, 238-248. 
162. Carattoli, A. Importance of integrons in the diffusion of resistance. Vet. Res. 2001, 32, 243-259.

163. Hall, R.M.; Collis, C.M. Mobile gene cassettes and integrons: Capture and spread of genes by site-specific recombination. Mol. Microbiol. 1995, 15, 593-600.

164. Corrêa, F.E.L.; da Silva Dantas, F.G.; Grisolia, A.B.; do Amaral Crispim, B.; Oliveira, K.M.P. Identification of class 1 and 2 integrons from clinical and environmental Salmonella isolates. J. Infect. Dev. Ctries. 2014, 8, 1518-1524.

165. Huang, Y.W.; Hu, R.M.; Lin, Y.T.; Huang, H.H.; Yang, T.C. The contribution of class 1 integron to antimicrobial resistance in Stenotrophomonas maltophilia. Microb. Drug Resist. 2015, 21, 90-96.

166. Tribuddharat, C.; Fennewald, M. Integron-mediated rifampin resistance in Pseudomonas aeruginosa. Antimicrob. Agents Chemother. 1999, 43, 960-962.

167. Guerin, É.; Cambray, G.; Sanchez-Alberola, N.; Campoy, S.; Erill, I.; da Re, S.; Gonzalez-Zorn, B.; Barbé, J.; Ploy, M.C.; Mazel, D. The SOS response controls integron recombination. Science 2009, 324, 1034-1034.

168. Hocquet, D.; Llanes, C.; Thouverez, M.; Kulasekara, H.D.; Bertrand, X.; Plésiat, P.; Mazel, D.; Miller, S.I. Evidence for induction of integron-based antibiotic resistance by the SOS response in a clinical setting. PLoS Pathog. 2012, 8, e1002778.

169. Wright, G.D. The antibiotic resistome: The nexus of chemical and genetic diversity. Nat. Rev. Microbiol. 2007, 5, 175-186.

170. Perry, J.A.; Westman, E.L.; Wright, G.D. The antibiotic resistome: What's new? Curr. Opin. Microbiol. 2014, 21, 45-50.

171. Fernández, L.; Álvarez-Ortega, C.; Wiegand, I.; Olivares, J.; Kocíncová, D.; Lam, J.S.; Martínez, J.L.; Hancock, R.E. Characterization of the polymyxin B resistome of Pseudomonas aeruginosa. Antimicrob. Agents Chemother. 2013, 57, 110-119.

172. Breidenstein, E.B.; Khaira, B.K.; Wiegand, I.; Overhage, J.; Hancock, R.E. Complex ciprofloxacin resistome revealed by screening a Pseudomonas aeruginosa mutant library for altered susceptibility. Antimicrob. Agents Chemother. 2008, 52, 4486-4491.

173. Alvarez-Ortega, C.; Wiegand, I.; Olivares, J.; Hancock, R.E.; Martínez, J.L. The intrinsic resistome of Pseudomonas aeruginosa to $\beta$-lactams. Virulence 2011, 2, 144-146.

(C) 2015 by the authors; licensee MDPI, Basel, Switzerland. This article is an open access article distributed under the terms and conditions of the Creative Commons Attribution license (http://creativecommons.org/licenses/by/4.0/). 